\title{
The outside determinants influencing quality of accounting human resources for sustainability through the lens accounting service firms in Hanoi, Vietnam
}

\author{
Son Tung Ha ${ }^{a}$, Hoai Dung Thi Nguyen ${ }^{a}$, Ngoc Anh Thi Nguyen ${ }^{a}$ and Duc Tai Do ${ }^{b^{*}}$
}

${ }^{a}$ National Economics University, Vietnam

${ }^{b}$ University of Labor and Social Affairs, Vietnam, Vietnam

\begin{tabular}{l}
\hline C H R O N I C L E \\
\hline Article history: \\
Received: August 182019 \\
Received in revised format: \\
August 182019 \\
Accepted: September 20, 2019 \\
Available online: \\
September 20, 2019 \\
\hline Keywords: \\
Outside determinants \\
Quality of accounting human \\
resources \\
Accounting service firms \\
Sustainability \\
\hline
\end{tabular}

\section{A B S T R A C T}

\begin{abstract}
This paper is conducted to investigate the impact levels of outside determinants on the quality of accounting human resources for sustainability of the accounting service firms in Hanoi. Data are collected using 145 questionnaires from accounting service firms. Based on the data collected, we use Cronbach's Alpha, EFA and regression model for learning the effect of different variables on the quality of accounting human resources. The results show that three outside determinants including International integration of accounting, Policy of accounting human resource development and Accounting labor market needs had positive relationships with the quality of accounting human resources. Based on the findings, some recommendations are given for improving the quality of accounting human resources of accounting service firms in Hanoi to ensure sustainability, including applying international financial report standard (IFRS) in Vietnam, strengthening cooperation between universities and businesses, and improving the quality of the labor market.
\end{abstract}

(C) 2020 by the authors; licensee Growing Science, Canada

\section{Introduction}

When participating in the World Trade Organization (WTO) and signing bilateral free trade agreements, and multilateral free trade agreements including Comprehensive and Progressive Agreement for Trans-Pacific Partnership (CPTPP), AccountingAuditing sector is one of 8 sectors having agreement on freedom of labor movement among member countries. All countries create favorable conditions and opportunities for their national workers to easily work in other member countries and vice versa, the workers of member countries also come to work in their own countries. Such integration brings to Vietnam the opportunity to attract foreign investment. The anticipated increase in FDI is expected to lead to a further expansion of services sectors and boost productivity growth. This also leads to expansion of domestic enterprises for business development. This is also a chance to help Vietnam diversify labor in accounting and auditing and strengthen integration with the region in the field of accounting and auditing (Tran \& Nguyen, 2017). As regular changes in tax regulations and accounting policies, the number of companies providing accounting services in Vietnam increases. Accounting Services firms have shown their various roles such as: (i) helping customers understand the Party's and State's guidelines and policies; (ii) advising business owners on selecting suitable business management organization; and (iii) helping business owners and businesses have accurate information. However, these firms have to struggle with some challenges related to updating knowledge and exchanging information between members with Vietnam Association of Accounting and Auditing (VAA), lacking of general regulations and professional qualifications of accounting human resources are not suitable with their requirements (Mai, 2013). It is undoubted that at the intersection of global economy and the natural environment, sustainability would be the best practices to provide the road maps for the success of business owners. As Marglin (2013) notes, a new economy requires a new rules

* Corresponding author.

E-mail address: taiketoanquocte@gmail.com (D. T. Do) 
and regulations such as the reorientation of both the demand and supply sides of growth. This requires a fundamentally different role of the market recognizing the limits of the invisible hand resulting in different economic, social and environmental problems. The new economy also requires firms in general and accounting service firms in particular to have high quality accounting human resources. On one hand, high quality accounting human resources are skillful enough to meet requirements of companies in integration context. On the other hand, high quality accounting human resources with intellectual development and well education will help to reduce an organization's ecological impact (e.g. ecological footprint) or to reduce the consumption of resources and energy (Ehnert et al., 2015). Admittedly, quality of accounting human resources is affected by many determinants. In the accounting service firms, human resource accounting is mainly responsible for all activities of the companies. The sustainable development of the company, accounting human resource plays the most important role, creating value for the goals set by the company (Do et al. 2019a). Vietnam's economy is increasingly integrating deeply with the world economy. Foreign investment in Vietnam is constantly increasing, Korea and Japan are the leading countries in investing in Vietnam. Therefore, it is indispensable for the Ministry of Finance to build an international financial report standard (IFRS) application roadmap in Vietnam. The accounting service firms in Hanoi have many development opportunities. However, companies are also facing several challenges from the IFRS application roadmap. Those challenges need a full assessment to maintain the growth of service quality provided by accounting service firms. In those challenges, the quality of accounting human resources (HR) is a factor that has a great influence on the development, success or failure of accounting service firms. Therefore, it is necessary to analyze, evaluate and measure the quality of accounting human resources and factors affecting the quality of accounting human resources. Thus, this paper aims to analyze and measure outside determinants influencing quality of accounting human resources for sustainability, specialize for accounting service firms in Hanoi, Vietnam.

\section{Literature Review}

The most widely acknowledged definition of sustainability that has emerged over time is the triple bottom line (TBL) consideration of economic viability, social responsibility, and environmental responsibility (Yu \& Zhao, 2015). From a business perspective, sustainability is the company's ability to achieve its business goals and increase long-term shareholder value by integrating economic, environmental and social opportunities into business strategies (Symposium on Sustainability, 2001). Many strategic human resource management scholars offer helpful perspectives on HR's role (e.g., Jamrog \& Overholt, 2004; Ulrich, 1997; Wright \& McMahan, 1992), particularly in regard to human resources and sustainability (Doppelt, 2003; Bradbury, et al., 2005; Losey, et al., 2005). In that light, quality of human resources is viewed as an important role for sustainability. Indeed, there are some factors that influent on quality of human resources for sustainability. To accounting firms, the study focused on three outside factors that affect the quality of accounting human resources, namely: (i) International integration of accounting, (ii) Policy of accounting human resource development and (iii) Accounting labor market needs.

\section{International integration of accounting}

The process of international integration in accounting is taking place on a large scale in all over the world. The process of integrating national accounting standards with international accounting standards will not happen easily and quickly in any country, including developed countries. Therefore, if there is no well preparation from the beginning, firms will surely encounter big mistakes and obstacles when integrating with international accounting standards (IAS). Stemming from the above problems, all countries need to have a clear strategy with solid steps to fully prepare the force for the integration process (Ho, 2010). The research results show the current status of international integration strategy in accounting in some countries in the world such as the European Union and continental European countries, the US and Canada and China. Since then, the author concludes the lessons for Vietnam on international integration in accounting such as setting objectives, developing and announcing strategic roadmap and solutions. Although Vietnam's accounting innovations took place in the 1980s, it was not until 1994, when preparing for the 1996 accounting system, Vietnamese accounting was directed towards international integration. In 1998, with the help of the European Union, Vietnam began to build a system of Vietnamese accounting standards and announced its implementation plan. The result of this process is from 2001 to 2007, the Ministry of Finance issued 26 Vietnamese accounting standards (VAS) and guiding circulars. Also, in this year, the enterprise accounting system was revised along with the promulgation of a small and medium enterprise accounting system (Vu \& Trinh, 2008). In addition, the authors also presented the international accounting integration strategy of the European Union, Canada, China, and Southeast Asian countries. It is stated that it is necessary to have a new strategy in which there must be a distinction between the type of enterprises in international integration of accounting. One of the most important strategic solutions for international integration is to develope a team of accountants and auditors through developed and upgraded training programs towards the approach international accounting standards. Phan (2016) belived that the market of unified accounting and auditing services requires preparation in all member countries on the legal framework, on the harmonization of standards, auditing standards, closing the gap of differences, on the coordination and consistency of the training program and training content; examination and assessment of training quality, service quality, mutual recognition of each country's practice certificates.

Policy of accounting human resource development

The participation of enterprises in the training process needs to be more substantive through the mechanism of financial investment for training and plays an important role in practical skills training for students who are studying accounting and 
auditing major at universities. Businesses cannot just stand outside to welcome graduates and ask them to start working as they need and complain that students do not meet the requirements of working skills (Le \& Pham, 2010). The overall objective of the accounting - auditing strategy to 2020 , vision to 2030 is to create a complete accounting and auditing system in accordance with the management mechanism of the State of Vietnam and professional development of regional and global accounting and auditing in order to satisfy information requirements for management, administration and control of economic resources, economic and financial activities of the country (Government, 2013). In recent years, the number of students in accounting and annual training courses of training institutions has been increased rapidly. However, the professional qualifications, foreign language skills and other soft skills are not high, not yet reached the general ground of the region. Human resources in the accounting and auditing sectors now form two types: mediocre human resources and high-quality human resources. Mediocre human resources account for a large number, meanwhile, high quality human resources account for a very low rate (Phan, 2016).

\section{Accounting labor market needs}

Regional trade agreements (RTAs) are increasing in number and becoming more and more complex. In 1990, only fifty trade agreements were in force while there were more than 280 in 2017 (Hofmann et al., 2017). There are some discussions on the impacts of trade agreements, which have been concluded or are being negotiated in developing countries. The participation in Comprehensive and Progressive Agreement for Trans-Pacific Partnership (CPTPP) and in ASEAN economic community (AEC) brings some challenges to Vietnam, in which the competition is fierce in the domestic accounting service market while the human resources in accounting and auditing sector of Vietnam is still weak in terms of competitiveness from both an enterprise perspective and an auditor's perspective (Phan, 2016). The author also stated that Vietnam and some countries in the region are facing the lack of international accounting and auditing resources. Currently, the number of students studying accounting and auditing is increasing, which is considered to be positive signals that there is a good potential of human resources. In addition, the labor market in general and market in the field of accounting - auditing in particular have to face with some challenges. If there is no time to innovate to meet the demands of the labor market, the unemployment rate of Vietnamese workers may increase, considerably. The field of accounting and auditing also does not avoid difficulties and challenges (Nguyen \& Nguyen, 2016). The above analyses have identified some outside factors that influence the quality of accounting human resources in Vietnam. However, these studies only use qualitative research methods, the scope of research on time from 2016 onwards. Besides, no research has been conducted so far to analyze and measure the impact of outside factors influencing the quality of accounting human resources in accounting service firms in Hanoi. By inheriting those previous studies, this research by selecting appropriate research methods continues to expand and develop a new model to analyze, evaluate and measure the influence of outside determinants on the quality of accounting human resources in accounting service firms in Hanoi.

\section{Research Methodology}

In order to achieve the objectives of this paper, we rely on the theoretical concept of the previous studies and the results of qualitative research through expert interviews and model analysis. On the other hand, we combined with the inductive method to verify, based on qualitative research results, to adjust and add observation variables to the questionnaire for conducting quantitative research. Inheriting the results of research by Vu and Trinh (2008), Ho (2010), Le and Pham (2010), Mai (2013), Phan (2016), Nguyen et al. (2017), Do et al. (2019b) and Tran et al. (2019) and using qualitative research approach through interviews with experts to perform quantitative research, we identified three outside determinants that affect the quality of accounting human resources, i.e. (i) International integration of accounting (IIA), (ii) Policy of accounting human resource development (PAHRD) and (iii) Accounting labor market needs (ALMN). Then, we conducted a questionnaire consisting of 10 observation variables with a 5-point Likert scale. Independent variables were measured from 1 "without effect" to 5 "strongly". The method of data collection was done through the survey and subjects are accountants in Accounting Service Firms doing business in Hanoi. We sent 200 questionnaires and received the feedback of 160. After checking the information on the votes, there are 145 questionnaires with full information for data entry and analysis, the size of this sample is consistent with study of Hair et al. (2006) $(n=50+8 \times m=50+8 \times 3=74)$. Therefore, the rest of observations for model 1 are 145 surveys, including 100\% participants who are chief accountants, general accountants and accountant staff in Accounting Service Firms in Hanoi. Participants mostly have Bachelor degree or higher. As can be seen, all participants are at high quality of accounting knowledge, and this makes surveys' answer become reliable. We have employed EFA analysis and regression model to determine the impact levels of outside determinants on quality of accounting human resources. The proposed model is shown in Fig. 1.

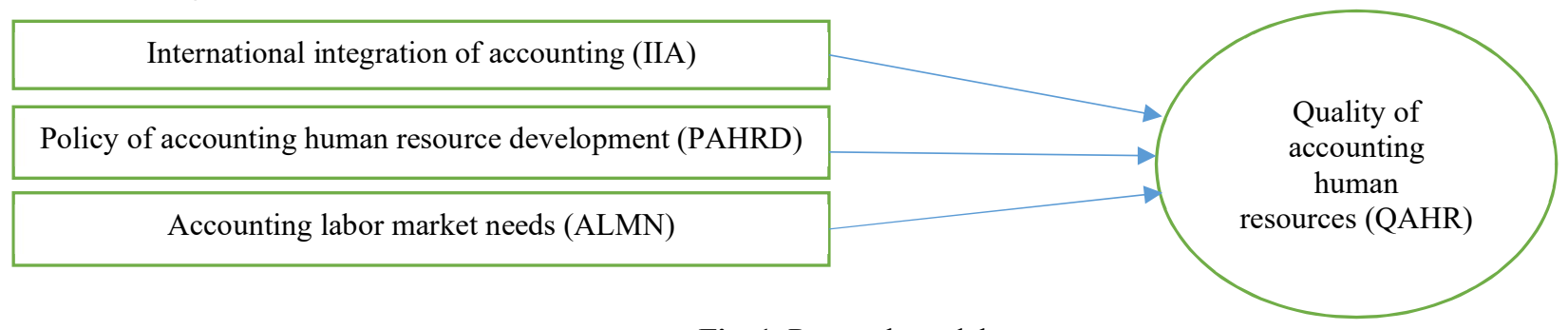

Fig. 1. Research model 
Dependent variable: Quality of accounting human resources is measured via accountant's intellectual competence (Do et al., 2019b), accountants' physical and mental strengths (Tran et al., 2019).

Independent variables: The independent variables are described as below

\begin{tabular}{ll}
\multicolumn{1}{c}{ Code } & Variables \\
\hline International integration of accounting (IIA) \\
$\begin{array}{ll}\text { IIA1 } & \text { IFRS application roadmap in Vietnam } \\
\text { IIA2 } & \text { Moving accounting workers between countries } \\
\text { IIA3 } & \text { The accounting practice certificates of each country are increasingly recognized by many countries } \\
\text { Policy of accounting human resource development (PAHRD) } \\
\text { PAHRD1 } & \text { The goal of the Government is to build an appropriate accounting system } \\
\text { PAHRD2 } & \text { The Government directs the development and improvement of the accounting profession } \\
\text { PAHRD3 } & \text { Accounting training institutions increasingly focus on training high-quality accountants, approaching } \\
\text { the IFRS approach } & \text { The training coordination between schools and businesses is increasing } \\
\text { PAHRD4 } & \text { Intense competition in the accounting labor market } \\
\text { Accounting labor } & \text { market needs (ALMN) } \\
\text { ALMN1 } & \text { Demand for recruiting human resources accounting of FDI enterprises is high but requires high } \\
\text { ALMN2 } & \text { Vietnam and some countries in the region are facing a shortage of human resources in international } \\
\text { ALMN3 } & \text { accounting and auditing }\end{array}$ \\
\hline
\end{tabular}

\section{Results and Discussions}

\subsection{Research Results}

The result of descriptive statistics

Information of data collected are shown in Table 1 and Table 2 as follows:

Table 1

Respondents by Jobs

\begin{tabular}{clcccc}
\hline & & Frequency & Percent & Valid Percent & Cumulative Percent \\
\hline \multirow{2}{*}{ Valid } & Accounting staff & 79 & 54.5 & 54.5 & 34.5 \\
& General accounting & 51 & 35.2 & 35.2 & 10.3 \\
& Chief accountant & 15 & 10.3 & 10.7 & 100.0 \\
\cline { 2 - 6 } & Total & 145 & 100.0 & 100.0 & \\
\hline
\end{tabular}

Table 2

Respondents by work experience

\begin{tabular}{|c|c|c|c|c|c|}
\hline & & Frequency & Percent & Valid Percent & Cumulative Percent \\
\hline \multirow[t]{4}{*}{ Valid } & Less than 1 year & 58 & 40.0 & 40.0 & 40.0 \\
\hline & Over 3 years & 32 & 22.1 & 22.1 & 62.1 \\
\hline & From 1 to 3 years & 55 & 37.9 & 37.9 & 100.0 \\
\hline & Total & 145 & 100.0 & 100.0 & \\
\hline
\end{tabular}

Data in Table 1 and Table 2 show that among the 145 respondents, accounting staff accounted for 54.5\%, General accounting accounted for $35.2 \%$, while the remaining 15 were Chief accountant, accounted for $10.3 \%$. Of these, 145 respondents, Accounting human resources for less than 1 year is 58 , accounted for $40 \%$, Over 3 years accounted for $22.1 \%$, while the remaining 55, were from 1 to 3 years, accounted for $37.9 \%$.

Quality scale analysis result

By using scale analysis, it can eliminate inconsistent variables and reduce errors in the research model. Therefore, only variables which have total correlation coefficients (Corrected Item - Total Correlation) greater than 0.3 and Cronbach's Alpha coefficients equal or greater than 0.6 are accepted (Hoang \& Chu, 2008). Analyzing Cronbach's Alpha analysis of outside determinants have shown their influence on the quality of accounting human resources ( 3 determinants with 10 observed variables) and the result is presented in Table 3. The result shows that, all Cronbach's Alpha coefficients of population are above 0.6; all Corrected Item - Total Correlation of observed variables are above 0.3. So, all variables of research model are suitable for next analyses (Hair et al, 2006).

Table 3

Results of analysis of Determinants Confidence of Scales in the Model

\begin{tabular}{llcc}
\hline & & Cronbach's Alpha & Corrected Item-Total Correlation \\
\hline International integration of accounting & 3 & 0.881 & 0.686 \\
Policy of accounting human resource development & 4 & 0.744 & 0.495 \\
Accounting labor market needs & 3 & 0.856 & 0.678 \\
\hline
\end{tabular}


EFA were conducted and we used the method of extracting coefficients. The results of Component Analysis and Varimax, Analyzes yields 11 attributes for the independent variables.

Table 4

KMO and Bartlett's Test

\begin{tabular}{llc}
\hline Kaiser-Meyer-Olkin Measure of Sampling Adequacy. & .858 \\
\hline Bartlett's Test of Sphericity & Approx. Chi-Square & 982.887 \\
& Df & 45 \\
& Sig. & 0.000 \\
\hline
\end{tabular}

The results of factor analysis in Table 4 show that $0.5<\mathrm{KMO}=0.858<1$. Bartlett's testimony shows sig. $=0.000<0.05$. It means variables in the whole are interrelated. After implementing the rotation matrix, 3 determinants with factor load factor are greater than 0.5; Eigenvalues are greater than 1; the variance explained is $78.810 \%$, which demonstrates that research data analyzing factor discovery is appropriate. Through the quality assurance of the scale and the test of the EFA model, we have identified 3 determinants influencing the quality of accounting human resources.

Regression Model Analysis Result

Based on adjusted model after the exploratory factor analysis, we have a multiple regression model as follows,

$\mathrm{QAHR}=\alpha+\beta_{1} \mathrm{IIA}+\beta_{2} \mathrm{PAHRD}+\beta_{3} \mathrm{ALMN}$

Table 5

Model Summary

\begin{tabular}{ccccc}
\hline Model & $\mathrm{R}$ & R Square & $\begin{array}{c}\text { Adjusted R } \\
\text { Square }\end{array}$ & $\begin{array}{c}\text { Std. Error of the Esti- } \\
\text { mate }\end{array}$ \\
\hline 1 & $.583^{\mathrm{a}}$ & .532 & .216 & .570304 \\
\hline
\end{tabular}

a. Predictors (Constant): Accounting labor market needs (ALMN), International integration of accounting (IIA), Policy of accounting human resource development (PAHRD)

b. Dependent Variable: Quality of accounting human resources (QAHR)

Table 6

Anova $^{\mathrm{a}}$

\begin{tabular}{llcccc}
\hline & & Model & Sum of Squares & Df & Mean Square \\
\hline 1 & Regression & 0.706 & 3 & .235 & .717 \\
& Residual & 46.301 & 141 & .328 \\
& Total & 47.007 & 144 & & \\
\hline
\end{tabular}

a. Dependent Variable: Quality of accounting human resources (QAHR)

b. Predictors: (Constant): Accounting labor market needs (ALMN), International integration of accounting (IIA), Policy of accounting human resource development (PAHRD)

Table 7

Coefficients $^{\mathrm{a}}$

\begin{tabular}{|c|c|c|c|c|c|c|c|}
\hline \multirow[t]{2}{*}{ Model } & \multicolumn{2}{|c|}{$\begin{array}{c}\text { Unstandardized } \\
\text { Coefficients }\end{array}$} & \multirow{2}{*}{$\begin{array}{c}\text { Standardized } \\
\text { Coefficients } \\
\text { Beta } \\
\end{array}$} & \multirow[t]{2}{*}{$\mathrm{T}$} & \multirow[t]{2}{*}{ Sig. } & \multicolumn{2}{|c|}{$\begin{array}{l}\text { Collinearity } \\
\text { Statistics }\end{array}$} \\
\hline & B & Std. Error & & & & Tolerance & VIF \\
\hline (Constant) & 3.962 & .271 & & 14.596 & .000 & & \\
\hline IIA & .232 & .084 & .135 & 2.278 & .043 & .443 & 1.856 \\
\hline PAHRD & .541 & .130 & .178 & 3.185 & .038 & .310 & 1.924 \\
\hline ALMN & .351 & .083 & .133 & 1.215 & .027 & .584 & 1.712 \\
\hline
\end{tabular}

a. Dependent Variable: Quality of accounting human resources (QAHR)

Results of the Table 5, 6, 7 show that:

Multicollinearity testing: all variance inflation factors (VIF) of independent variables are under 2, so multicollinearity of model is low (Hoang \& Chu, 2008). Therefore, this regression model does not have any violation of the CLRM basic assumption. Durbin - Watson statistic which is used to test the autocorrelation of residuals presents the model does not violate when using multiple regression method because Durbin - Watson value is 2.282 (in the interval of 1 and 3). In other words, the model is indicated no autocorrelation of residuals (Hoang \& Chu, 2008). ANOVA testing result: Level of significant (Sig.) $=0.004$ implies that multiple regression model is suitable with data. Coefficient of $\mathrm{R}^{2}$ ( $\mathrm{R}$ Square) $=0.532$, which means $53.2 \%$ of the total variation in the quality of accounting human resources will be explained by the regression model. Research model result indicates that all independent variables; namely International integration of accounting (IIA), Policy of accounting human resource development (PAHRD) and Accounting labor market needs (ALMN) are significant (because Sig. $<0.05)$ to the quality of accounting human resources. Determinants have influences on the quality of accounting human resources are presented in the following standardized regression model: 


\subsection{Discussions}

\section{International integration trend of accounting}

The Vietnamese economy has been integrated with the regional and global economies. It is inevitable that accounting and auditing sectors must participate in the integration process. Accounting human resources should be developed in sufficient quantity and quality to be able to meet requirements from integration. Accountants are required not only to provide sustainability information, but also to have it audited. Thus, accountants need to be trained and re-trained to enhance professional qualifications, occupational skills, health and working attitude to meet higher and higher requirements of the accounting labor market. This idea is supported that globalization changes in the nature of work. This puts a premium on a set of meta-skills, such as agility, flexibility, grit, and learning how to learn (McKinsey Global Institute, 2017). Currently, more than 130 countries and territories around the world have officially announced the application of IFRS in various forms. In particular, about 119 countries and territories have required mandatory use of IFRS standards for all or most domestic public interest units. The countries that apply IFRS have achieved certain results. In Vietnam, the Ministry of Finance has developed a roadmap and plan for applying IFRS, specifically as follows:

(i) Preparation of conditions for implementation: From 2019 to the end of 2021, the Ministry of Finance prepares necessary conditions to implement the project and ensure support for enterprises to start applying IFRS from 2022;

(ii) Stage 1: From 2022 to 2025 - The period of voluntary;

(iii) Stage 2: From after 2025 - Required period;

(iv) Scope and method of application of IFRS: Enterprises subject to IFRS application must apply all IFRSs that are already implemented under the provisions of the International Accounting Standards Committee (IASC) at the same time. When the International Accounting Standards Committee has an amendment, supplement or replacement of IFRS, it is necessary to apply within 1 year from the time of amendment, supplement or replacement of IFRSs in effect. Enterprises apply voluntarily or compulsorily IFRS on a consistent basis throughout the fiscal year. The financial statements of enterprises set up by IFRS will be replaced for the financial statements prepared according to Vietnamese accounting standards (VAS) to publish according to the Vietnamese accounting law.

\section{Policy of accounting human resource development}

The overall objective of developing human resources in Vietnam in the period of 2011-2020 is to bring Vietnamese manpower to become the most important foundation and advantages for sustainable development of the country, international integration, social stability and improving the level of competitiveness of our country's human resources up to the level of advanced countries in the region, some of which approach the level of developed countries in the world (Government, 2011). Thus, the orientation of human resource development must meet the needs of social-economic development in terms of both the quantity and quality of human resources, on the basis of improving the productivity of labor and professional qualification and training of the workforce. Besides, the Government also planned policies to create a legal environment for human resources development in both quality and quantity such as educational socialization policies; policies of developing high-quality education and training establishments up to regional and international standards; learning content reform policies, methods of education and training; policies on health, workers' health care, labor safety and hygiene policies. Currently, universities and colleges have changed their training programs in a way that is suitable for employers. Many universities have associated with international professional organizations on accounting and auditing in Vietnam such as the Association of Chartered Certified Accountants (ACCA), Institute of Chartered Accountant in England and Wale (ICAEW), Certified Practicing Accountants Australia (CPA Australia) for high quality accounting training in a way that accountants can understand and apply IFRS into work and integrate international certificates in accounting. At that time, the accountant has the ability to participate in labor abroad, and has the capacity to participate with the international community to solve global issues about the region. The system of accounting training institutions affects the quality of the supply of accounting labor force to the market, indirectly affects the quality of human resources at accounting service firms. When the quality of accounting human resources at universities and colleges improves, it means that accounting service firms have the opportunity to recruit good qualified accountants, minimize retraining costs of each company. Besides, the development of the system of accounting training institutions also affects the health and longevity of accountants through the elements of income, awareness, economic - social and scientific information processing.

\section{Accounting labor market needs}

The accounting labor market is a collection of activities aimed at exchanging, buying and selling labor between employers and accountants; through which prices, conditions and employment contract relationships are determined. The development of the accounting labor market as an objective factor affects the improvement of the quality of accounting human resources in accounting service firms because the information of employment and labor is comprehensive, the competition becomes fierce in order to attract quality and quantity workers in accordance with the requirements of service provision. Tensions in the labor market influenced the significant growth of the functions of human resource specialists in areas such as the recruitment and selection of employees, labor security, followed by induction, appraisal, and employee training; a significant growth awaits such functions as administering the payroll, strategic planning and administration, the development of teamwork skills, projection of the organization, and change management (Česynienè et al., 2013). The major challenges facing the labor market 
in Vietnam include lack of skilled labor, the impact of industry 4.0, and the need for labor reforms due to the upcoming free trade agreements. Undoubtedly, quality of services providing by accounting service firms deeply depends on quality of accounting HR. Though accounting HR supplied by higher educations is large enough, it is accepted that qualified accountants who can apply IFRSs to their jobs is limited. In general, FDI firms continue to struggle in hiring skilled labor in Vietnam. According to the 2018 Global Talent Competitiveness Index (GTCI), which assesses countries in terms of their ability to attract, develop, and retain talent, Vietnam ranks 87th amongst 119 countries. Major challenges include the lack of technology infrastructure, R\&D spending, vocational, and technical skills. Many experts believe that, at present, our labor market is not of high quality, which partly affects the quality of human resources of organizations and units. Labor supply and labor demand create the labor market; there are many factors affecting the quality of labor supply and labor demand in the labor market. In accounting service firms, labor in the accounting sector is not a scarce type, it is relatively popular in universities and colleges. Therefore, the labor supply in the market is quite large, facilitating the public HR recruitment of accounting service firms. However, for high-quality and knowledgeable human resource accountants who can apply IFRSs to their jobs, service companies also face certain difficulties in recruitment and attracting talents because in the accounting labor market, the number of these candidates is quite limited. It is possible that the companies have to recruit for a long time but cannot find the right people to secure the position of providing accounting services for FDI firms.

\section{Recommendations}

From the above research results, the authors propose some recommendations to improve the quality of accounting human resources. These recommendations focus on analysis and evaluation of dependent variables and independent variables in the research model.

\section{Applying IFRS in Vietnam}

The Ministry of Finance of Vietnam should incorporate IFRS content as soon as possible as the official documents to accounting service firms, accounting lecturers, accountants, accounting students so that they can integrate in global market. Accounting professional organizations in Vietnam such as Vietnam Accounting and Auditing Association (VAA), international professional accounting and auditing organizations in Vietnam need to provide training courses on IFRS for accounting services firms, accounting lecturers, accountants and accounting students. Businesses, accounting lecturers, accountants and accounting students need to proactively develop specific plans for accessing, understanding and using IFRS.

\section{Strengthening cooperation between universities and businesses}

Cooperation between universities and businesses can be activated through seminars, law training, accounting training and accounting practices. With which, information provided by universities could be matched with demand from businesses. In that light, universities could not only understand recruitment needs, accounting work requirements but also build close relationships with businesses. According to the McKinsey Global Institute, only 13 to 19 per cent of 33 million university graduates in developing countries are suitable to work in a multinational company, due to their lack of language skills, low quality of educational system, and lack of cultural fit. Also, only a fraction of these people is willing or able to relocate to foreign countries for employment (McKinley Global Institute, 2005 - I). By connecting with businesses, universities can innovate and perfect the training accounting program in the direction of supplying knowledge to meet international standards, especially in IFRS. To some extents, incorporating sustainability content in accounting training is necessarily. This could help firms get high-quality information to understand the impact on society and the environment. As part of integration, firms need to show how they are doing on sustainability. In that light, accountants play a vital role. Accordingly, universities need to change educational system to include sustainability. From this survey information, universities continue to build close relationships with businesses to understand the situation and needs of businesses. Universities and Faculty of Accounting can invite employers to participate in the development of training programs. Besides, businesses also need to support universities by increasing financial investment for accounting training.

\section{Improving the quality of the labor market}

Vietnamese Government needs to have the plan preparing for the economy with a generation of young, skilled workers who are capable of long-term operations and have high technical and professional qualifications. On one hand, the government should provide retraining and advanced training for workers who are already working to meet requirements of global integration including sustainability understanding. In this case, the government has to introduce reforms in education and industrial training to bring it more in line with current industry demands. On the other hand, information of the labor market for accounting needs to be updated more frequently and publicly to both the supply and demand side of the labor market. This also completes information for universities and businesses in their working.

\section{Acknowledgment}

This research is funded by National Economics University, Hanoi, Vietnam under the decision number of No 154/QĐ ĐHKTQD, code CBQT2.2019.18 (154/QĐ-CBQT2.2019.18).

\section{References}

Bradbury, H., Robson, L., \& Waage, S. (2005). The role of OD in the move to sustainability. The OD Practitioner, 37(2), 1924. 
Česynienè, R., Diskienè, D., \& Stankevičienè, A. (2013). Labour market trends and their impact on human resource management in Lithuanian companies. Ekonomika, 92(3), 123-140.

Do, D.T, Tran, B.M, Nguyen, T.N.L, Truong, D.D, \& Tran, M.D. (2019a). Determinants influencing the quality of accounting human resources: The case of Hanoi, Vietnam, $10^{\text {th }}$ International conference socio - economic and environmental issues in development, 711-726.

Do, D.T., Doan, T.Q.A., Truong, D.D., \& Le, T.T. (2019b). Quality of Human Resources via Accountant's Intellectual Competence in Multinational Enterprises in Hanoi, Vietnam. International Journal of Small and Medium Enterprises and Business Sustainability, 4(1), 115-129.

Doppelt, B. (2017). Leading change toward sustainability: A change-management guide for business, government and civil society. Routledge.

Ehnert, I., Harry, W., Zink, K.J. (2015). Sustainability and Human Resource Management: Developing Sustainable Business Organizations (1st ed.), Springer Publisher.

Government (2011). Prime Minister's decision on Vietnam's human resource development strategy for the period 2011-2020, No 579/QD-TTg, April 19, 2011.

Government (2013). Approving accounting and auditing strategies to 2020, vision to 2030, No 480/QD-TTg, March 18, 2013

Hair, J.F., Anderson, R.E., Tatham, R.L., \& Black, W.C. (2006). Multivariate data analysis. Prentice-Hall, International, Inc.

Hoang, T., \& Chu, N.M.N (2008). Analysis of research data with SPSS. Hong Duc Publishing House.

Ho, T.V. (2010). Strategies for international integration of accounting in the world and lessons learned for Vietnam, Auditing Journal, 4(58), 51-53.

Hofmann, C., Osnago, A., \& Ruta, M., (2017). Horizontal Depth: A New Database on the Content of Preferential Trade Agreement. Policy Research working paper; no. WPS 7981. Washington, D.C.: World Bank Group.

Jamrog, J. J., \& Overholt, M. H. (2004). Building a strategic HR function: Continuing the evolution. Human resource planning, 27(1), 51-62.

Le, V.L, \& Pham, T.M.T. (2010). The relationship between universities and firms in improving the quality of human resource training of accounting and auditing majors. Auditing Journal, 6(1) 31-34.

Losey, M., Meisinger, S., \& Ulrich, D. (2005). The Future of Human Resource Management. Hoboken, NJ: John Wiley and Sons, Inc.

Mai, T.H.M. (2013). Vietnam Accounting Services, limitations to overcome, Accounting and Auditing Journal, 13(1), 7-9.

Marglin, A.S. (2013). Premises for a new economy \& act. Journal of Development, 56(2), 149-154.

McKinley Global Institute (2005). The Emerging Global Labor Market: Part I - The Demand for Offshore Talent in Services.

McKinsey Global Institute (2017). Jobs lost, jobs gained: Workforce transitions in a time of automation. McKinsey \& Company.

Nguyen, T.B.N \& Nguyen, T.T.M. (2016). Joining TPP and AEC - Opportunities and challenges for human resources in the field of accounting and auditing in Vietnam, Science and banking training Journal, 166(1), 77-80.

Phan, T. T.H. (2016). Improving the quality of accounting and auditing human resources in the integration period, Asian economy in the Pacific Journal, 4(1), 43-45.

Symposium on Sustainability (2001). Profiles in Leadership. New York City.

Tran, M.D. \& Nguyen, T.M. (2017). Discussion of accounting human resources in Hi - Tech Parks: Opportunities and Challenges when joining TPP and AEC, Accounting and Auditing Journal, 1(32), 22-26.

Tran, M.D, Do, D.T, \& Tung, H. S. (2019), Quality of personnel via accountant's physical and mental strength in multinational firms in Vietnam. The 15th Conference of International Federation of East Asian Management Associations in Kyoto (IFEAMA - 2019), 227-240.

Ulrich, D. (1997). Human Resource Champions. Boston: Harvard Business School Press.

Vu, H.D, \& Trinh, Q.V. (2008). Looking for a strategy for international integration of accounting in Vietnam, Journal of Development Economics, 12(1), 1-5.

Wright, P. M., \& McMahan, G. C. (1992). Theoretical perspectives for strategic human resource management. Journal of management, 18(2), 295-320.

Yu, M., \& Zhao, R. (2015). Sustainability and firm valuation: an international investigation, International Journal of Accounting and Information Management, 23(3), 289-307.

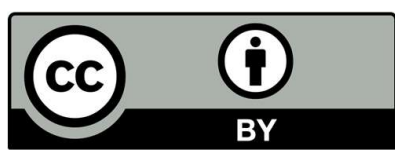

(C) 2020 by the authors; licensee Growing Science, Canada. This is an open access article distributed under the terms and conditions of the Creative Commons Attribution (CCBY) license (http://creativecommons.org/licenses/by/4.0/). 